\title{
Research on Audit Quality and Information Content of Internal Control Audit Reports
}

\author{
Wang Meiying \\ School of Business, Beijing Wuzi University, Beijing, China
}

Email address:

wyfwmywyx@126.com

To cite this article:

Wang Meiying. Research on Audit Quality and Information Content of Internal Control Audit Reports. Journal of Finance and Accounting. Vol. 3, No. 5, 2015, pp. 128-131. doi: 10.11648/j.jfa.20150305.13

\begin{abstract}
This paper examines investors' reaction to internal control audit reports by concerning audit quality, we find that companies disclosing unqualified internal control audit reports issued by Big 4 firms have higher earnings response coefficient. So the internal control audit reports can transmit information relevant to investment decisions, but its signals are associated with audit quality.
\end{abstract}

Keywords: Internal Control Audit, Audit Quality, Market Reaction

\section{Introduction}

Effective internal control can reduce the management risk and financial risk in companies. Since 2011, listed companies in China need to disclose the internal control audit reports. Employing the accounting firms to audit their internal control will increase cost and additional information disclosure risk, investors' reaction is the main concern of listed companies who send the signals. And also the implementation of the internal control audit is mainly required by the regulators, investors' concern of the internal control audit reports can really promote the internal control audit to play the role of improving the quality of accounting information, therefore, whether the internal control audit reports have information content is also concerned by regulators. Fu Liang Xuan (2010) studied the market reaction of voluntary disclosure of internal control audit reports in the A-shares listed companies from 2007 to 2009 and find that the internal control audit report has no information content ${ }^{[1]}$. As a result, we have the following questions: don't the investors care about the internal control auditing information? Or under the condition of imperfect internal control audit guidelines, investors will not be able to determine the reliability of internal control audit reports, which influences the signal role of internal control audit reports? Based on the above problems, combining with audit quality, this paper provides empirical evidence to the implement of internal control audit.

Based on the voluntary disclosing standard internal control audit reports of A-shares listed companies from 2007 to 2009, this paper examines the reaction of investors before and after the disclosure of internal control audit report by using event study. Previous research shows that audit quality affected investors' reaction, so in our study, all the companies are divided into two examples which are audited by Big Four accounting firms and non-Big Four to test whether audit quality can affect the the signal role of internal control audit reports. We find that only the internal control audit reports disclosed by the Big Four accounting firms have market reactions, so the internal control audit reports can transmit relevant information about investment decision, but the strength of the signal is affected by audit quality. Therefore, to improve the decision-making correlation of internal control audit reports, regulators should strengthen supervision of internal control audit and improve the reliability of reports. To sum up, the signal of Internal control audit reports is not strong, possible reason is that internal control regulations before 2009 were imperfect and supervision mechanisms had not been established. Investors are difficult to determine the reliability of the signal transmitted by the internal control audit reports, or information contained in internal control audit reports is consistent with other ones sent by companies.

\section{Theoretical Analysis and Research Hypothesis}

Information asymmetry exists inevitably between investors and the management of listed companies. Listed companies need to disclose a variety of regular or irregular information to 
reduce information asymmetry and avoid adverse selection behavior of investors. The information especially accounting earnings disclosed by companies is the basis for investors to make investing decision, due to the importance of accounting surplus data and its operability, management often choose to manipulate accounting data to achieve their opportunism purpose, resulting the reliability of accounting information is questionable. While accounting information quality is difficult to be directly observed, then the companies which have high quality accounting information are put in a comparative disadvantage position. Therefore, high quality companies try to take the initiative to send signals which can show that their earnings are more reliable in the capital market, and the signals should be difficult for low quality companies to imitate so that the investors can distinguish them from the other companies. Because effective internal control over financial reporting can provide reasonable assurance of the reliability of accounting information, hiring an independent accounting firm to verify the effectiveness of internal control becomes the favorable signal sent by the listing corporation. The CPA are considered to refuse to provide false reports for the companies whose internal control is not perfect in order to protect their reputation, especially for big accounting firms.

Whether the disclosure of internal control audit reports has information content is an important problem concerned by listing companies and regulators. Existing studies have shown that voluntary disclosure has information content ${ }^{[2]}$. Ashbaugh-Skaife et al.(2009) find negative stock price reactions to the disclosure of internal control weaknesses and material weaknesses ${ }^{[3]}$. Hammersley et al. (2008) find that the information content of internal control weakness depends on the severity of the internal control weakness ${ }^{[4]}$. Then the disclosure of internal control information is informative in America, but the information content of internal control reports in China is still a problem need to be verified empirically.

In recent years, the information disclosure of internal control has got increasingly attention, regulators require the listing companies to take internal control information disclosures as an important part of the annual reports, the effectiveness of internal controls is becoming one of the most important considerations in making investment decisions for investors. These voluntary disclosures of internal control audit reports have an unqualified audit opinion, that is to say the CPA think the company maintained effective internal control over financial reporting after their auditing. As we know, the financial statements audit is based on sampling analysis methods, therefore, for all companies received unqualified audit opinion on the financial statements, when CPA ensure that their internal control over the process of financial reports are effective, their quality of financial reports should be higher. Investors' reaction to reliable unexpected surplus should be stronger, previous study also suggests that there exists a positive correlation between earnings response coefficient (ERC) and reliability of financial reports ${ }^{[5]}$ (Teoh and Wong, 1993), thus this paper assumes that:

H1: The ERC of companies who voluntarily disclose internal control audit reports are higher than those undisclosed ones, that is to say voluntary disclosure of internal control audit reports has information content.

When the large accounting firms are found not to report significant financial misstatement of the listed companies, they will suffer more losses than small firms. At the same time, with higher competence and independence, and the existence of reputation mechanism, bigger accounting firms must do the auditing work more carefully, and the possibility of fraud is low. Therefore, the auditor size affect audit quality and investors can recognize the effect of firm size on audit quality ${ }^{[6][7]}$.And also, before the implementation of internal control auditing of domestic listing Corporation, the big 4 firms have experience of internal control auditing to America listing Corporation. Because of the more maturity of audit procedure and audit method and the existence of reputation mechanism, we can believe that the reliability of internal control audit reports disclosed by big 4 is higher and the reports have more information content, and thus we put forward the following hypothesis:

H2: Companies whose internal control audit reports audited by the Big Four have greater ERC.

\section{Model Specification and Sample Selection}

\subsection{Model Specification}

According to efficient market theory, the occurrence of the event will be quickly reflected by the fluctuation of stock prices in the stock market, then impact of the event can be evaluated by volatility of stock prices before and after the event, this is called event study method. If internal control audit reports disclosed by the listed companies can provide relevant information about investment decision, investors will change their expectation to the company's share price, then share price will behave erratically and generate excess return. Through observing this relevance of stock prices and disclosure events, we can ascertain whether internal control audit report has information content or not, as described below:

1) Confirm the event day

As internal control audit reports of all Shanghai Stock Exchange are disclosed along with annual reports, we take the date of annual reports as the event day. If the day of disclosure is non-trading day, we can take the next day as the event day.

2) Determine the event window

Generally recognizing, because "noise" of longer event window is larger, shorter event window can eliminate other information interference. The abnormal fluctuation of stock price can fully interpret the impact of event. This paper take $[-1,1],[-2,2]$ as the event window, and take $[-3,3]$ in robustness test.

3) Calculation of abnormal returns

The abnormal returns equal to effective rate of return in event window minus expected (normal) return. This paper selects market adjusted model to evaluate abnormal returns. 
Calculations of abnormal returns as follows:

the daily abnormal return (AR) of every sample company $\mathrm{i}$

\section{ARit=Rit-Rmt}

Which, Rit is the actual return ratio of company $i$, equals to daily individual stock returns considering of cash dividend; $\mathrm{Rmt}$ is daily market return ratio on the $\mathrm{t}$ day.

4) Calculate Cumulative abnormal returns (CAR) on the event window of $\left(t_{1}, t_{2}\right)$

$\mathrm{CAR}=\sum_{t=t 1}^{t 2}$ ARit $(\mathrm{t} 1$ is beginning day of the event window, t2 is closing day of the event window)

According to H1, ERC of companies who disclose internal control audit reports are higher than those non-disclosing, we examine information content of voluntary disclosure of internal control audit reports through model(1):

$$
\begin{gathered}
\mathrm{CAR}=\lambda_{0}+\lambda_{1} \mathrm{UE}+\lambda_{2} \mathrm{ICR}+\lambda_{3} \mathrm{UE}^{*} \mathrm{ICR}+\lambda_{4} \mathrm{MV}+ \\
\lambda_{5} \mathrm{BETA}+\lambda_{6} \mathrm{MB}+\lambda_{7} \mathrm{LEV}+\varepsilon
\end{gathered}
$$

Table 1 is the variable definition in Model (1). Of which, unexpected surplus equals to actual earnings per share minus expected earnings per share. We take actual surplus last year as expected earnings. We focus on the coefficient of interaction $\lambda 3$ in this model, when $\lambda 3$ is significantly positive, that means ERC of voluntary disclosing companies are higher than non-disclosing ones, then unqualified internal control audit reports mean that accounting information of listed firms is more reliable. Control variables include corporate risk(BETA), growth and persistence (MB), scale of company(MV).

Table 1. Variable Definition.

\begin{tabular}{ll}
\hline & Variable Definition \\
CAR & market-adjusted cumulative abnormal returns between $\left(\mathrm{t}_{1}, \mathrm{t}_{2}\right)$ \\
UE & unexpected earnings \\
MB & market-to-book ratio in the end of period \\
BETA & system risk \\
MV & natural logarithm of market value in the end of period \\
\hline
\end{tabular}

\subsection{Sample Selection}

The listed companies also report other important announcements while disclosing the annual reports, which can influence the reliability of the results. So following Hammersley et al. (2008), we delete firms that reported other important announcements in event window, which including reorganized assets, surplus forecast, desterilization of restricted shares, quarterly reports, and significant litigation. Only in this way, we can interpret the results into the influence of internal control audit reports.

We divide the sample firms into the Big4 and non-Big4 clients, and use multiple regressions respectively to explore the influence of different internal control audit quality on investors. There are 127 sample firms belong to Big4 clients, and 22 of them have disclosed unqualified audit opinion on internal control. In addition, there are 1344 sample firms belong to non-Big4 clients, and 292 of them have voluntary disclosure.

\section{Empirical Test}

\subsection{Descriptive Statistics}

Table 2 lists the comparative analysis of disclosing Sample Firms and non-disclosing Firms. As we can see, the LEV, MV of disclosing companies are significantly higher than non-disclosing ones, the MB and BETA are lower than the non-disclosing corporate at $10 \%$ level of significance. The Pearson correlation coefficients between the variables are less than 0.32 , therefore, the model is less likely to exist multicolliearity.

Table 2. Descriptive Statistics.

\begin{tabular}{llllll}
\hline \multirow{2}{*}{ Variables } & \multicolumn{2}{l}{ Non-Disclosing Firms } & \multicolumn{2}{l}{ Disclosing Firms } & \multirow{2}{*}{ T -test } \\
\cline { 2 - 5 } & mean & median & mean & median & \\
\hline UE & 0.047 & 0.02 & -0.002 & 0.016 & $1.80^{*}$ \\
MV & 22.3 & 22.2 & 22.8 & 22.6 & $-5.85^{* * *}$ \\
MB & 1.91 & 1.61 & 1.78 & 1.49 & $1.70^{*}$ \\
BETA & 1.03 & 1.06 & 1.01 & 1.04 & $1.67^{*}$ \\
LEV & 0.50 & 0.50 & 0.52 & 0.54 & $-1.88^{*}$ \\
\hline
\end{tabular}

\begin{tabular}{|c|c|c|c|c|c|c|c|c|}
\hline Event Window & {$[-1,0]$} & & {$[-2,0]$} & & {$[0,1]$} & & {$[0,2]$} & \\
\hline & coefficient & P-value & coefficient & P-value & coefficient & P-value & coefficient & P-value \\
\hline CONSTANT & -0.03 & 0.68 & -0.01 & 0.87 & 0.03 & 0.71 & -0.02 & 0.84 \\
\hline UE & 0.01 & $0.07 *$ & 0.01 & $0.09 *$ & -0.01 & 0.12 & 0.02 & $0.04 * *$ \\
\hline ICR & 0.01 & 0.26 & 0.01 & 0.48 & -0.01 & 0.11 & -0.01 & 0.65 \\
\hline UE*ICR & 0.01 & 0.71 & -0.01 & 0.86 & 0.03 & $0.01 * *$ & 0.04 & $0.03 * *$ \\
\hline MV & 0.00 & 0.64 & 0.00 & 0.99 & -0.00 & 0.67 & 0.00 & 0.70 \\
\hline BETA & 0.00 & 0.30 & 0.02 & 0.34 & 0.02 & 0.43 & 0.01 & 0.80 \\
\hline LEV & -0.04 & $0.03 * *$ & -0.03 & 0.17 & -0.02 & 0.35 & -0.03 & 0.25 \\
\hline $\mathrm{R}^{2}$ & 0.072 & & 0.004 & & 0.056 & & 0.046 & \\
\hline $\mathrm{N}$ & 127 & & 1344 & & 127 & & 127 & \\
\hline
\end{tabular}

Talbe 3. Multiple Regression Analysis of the Big Four Samples in 2007-2009.

\subsection{Multiple Regression Analysis}

Table 3 reports the multiple regression analysis results of
Big4 clients in the event window. In the $[0,1],[0,2]$ event window, the interaction coefficient is Significant positive, In $[-2,0],[-1,0]$ event window, interaction coefficient is not 
significant. Therefore, after disclosing audit reports issued by the Big 4, investors make positive reaction significantly. Table 4 reports multiple regression results of non big 4 clients, but we find no reaction of investors, interaction coefficient is not significant. According to the different results of two samples, internal control audit reports can deliver relevant information to investors, but this information content is relevant to audit quality. So regulators should strengthen supervision of internal control audits, improve internal control audit quality. Only in this way internal control audit reports can provide valuable information to investors

Table 4. Multiple Regression Analysis of Non Big Four Clients in 2007-2009.

\begin{tabular}{|c|c|c|c|c|c|c|}
\hline \multirow{2}{*}{ Event Window } & \multirow{2}{*}{$\begin{array}{l}{\left[\begin{array}{l}-1,1 \\
\text { coefficient }\end{array}\right.} \\
\end{array}$} & \multicolumn{2}{|r|}{$[-2,2]$} & \multicolumn{2}{|r|}{$[-3,3]$} & \multirow[b]{2}{*}{ P-value } \\
\hline & & P-value & coefficient & P-value & coefficient & \\
\hline CONSTANT & -0.003 & 0.931 & -0.042 & 0.406 & -0.013 & 0.818 \\
\hline UE & -0.006 & $0.089 *$ & -0.003 & $0.075^{*}$ & -0.009 & 0.203 \\
\hline ICR & 0.003 & 0.453 & 0.004 & 0.323 & 0.007 & 0.147 \\
\hline UE*ICR & 0.004 & 0.703 & -0.000 & 0.976 & -0.006 & 0.698 \\
\hline MV & 0.001 & 0.714 & 0.002 & 0.239 & 0.001 & 0.645 \\
\hline BETA & -0.004 & 0.712 & -0.011 & 0.390 & -0.016 & 0.236 \\
\hline LEV & -0.014 & 0.124 & -0.008 & 0.510 & 0.001 & 0.962 \\
\hline $\mathrm{R}^{2}$ & 0.006 & & 0.004 & & 0.005 & \\
\hline $\mathrm{N}$ & 1344 & & 1344 & & 1344 & \\
\hline
\end{tabular}

\section{Research Conclusions and Shortcomings}

The response of investor to internal control audit reports is an important concern of listed companies and regulators. Different from previous research, this paper takes the influence of audit quality into consideration, we divide all the sample companies into two parts: the big four clients and the non-big four ones. We find that internal control audit reports issued by big four clients delivered information relevant of decisions. So investors in China focus on internal control audit information, but this information content is relevant with audit quality, regulators should focus on improving quality of internal control audit.

The shortcoming of this paper is the small number of samples audited by the big four, this may affect reliability of research conclusion. Moreover, signal of internal control audit reports is still low, possible reasons are as follows: firstly, shortage of supervision and punishment mechanism in the voluntary disclosure stage. Therefore, the reliability of unqualified audit reports are still questionable. Secondly, previous research find that profitability, corporate governance, accounting information quality of disclosing companies are better than non-disclosing ones, information in unqualified audit report is consistent with other information sent by listed companies, which restrict the signal effect.

\section{References}

[1] Fu Liang Xuan, A study of market reactons on disclosure of internal control assurance reports of listed company, Inner Mongolia University, 2010, Master Dissertation.

[2] Healy, P., Hutton, A., and Palepu, K., Stock performance and intermediation changes surrounding sustained increases in disclosure, Contemporary Accounting Research, $1999,16, p$ 485-520.
[3] Hollis Ashbaugh-Skaife,Daniel W.Collins,William R.Kinney Jr.And Ryan Lafond 2009, The Effect Of Sox Internal Control Deficiencies On Firm Risk And Cost Of Equity, Journal Of Accounting Research Vol.47 No.1 [4]Hammersley,J.,Myers,L., and Shakespeare, C., Market Reactions to the Disclosure of Internal Control Weaknesses and to the Characteristics of those Weaknesses under Section 302 of the Sarbanes Oxley Act of 2002, Review of Accounting Studies, 2008, 13,p141-165.

[4] Hammersley, J., Myers, L., and Shakespeare, C., Market Reactions to the Disclosure of Internal Control Weaknesses and to the Characteristics of those Weaknesses under Section 302 of the Sarbanes Oxley Act of 2002 ,Review of Accounting Studies, 2008, 13,p141-165

[5] Teoh, S.H., and Wong, T.J., Perceived Auditor Quality and the Earnings Response Coefficient, The Accounting Review, 1993,68,p346-366.

[6] Wen Guo Shan, Accounting firm scale, Audit quality and market reactions, Audit and Economy Research, 2009, 11: p34-45.

[7] Zhang Juan, Li Hu, Wang Bing, Auditor choice, signal transmission and capital structure optimization, Audit and Economy Research,2010, 9, p33-39.

[8] Brown, S., and Warner, J., Using daily stock returns: The case of event studies, Journal of Financial Economics, $1985,3, \mathrm{p} 3-31$.

[9] Collins, D.W., and Kothari, S.P., An Analysis of Intertemporal Cross-Sectional Determinants of Earnings Response Coefficients, Journal of Accounting \& Economics, 1985,11,p143-181.

[10] Ball, R. J.,and Brown, P., An Empirical Evaluation of Accounting Income Numbers, 1968,Journal of Accounting Research,Autumn,p159-178

[11] Ball, R. and Kothari, S. P., Security Returns around Earnings Announcements, The Accounting Review, 1991, 10, p718-738. 